\title{
Timber Logging in Central Siberia is the Main Source for Recent Arctic Driftwood
}

Author(s): Lena Hellmann, Willy Tegel, Alexander V. Kirdyanov, Ólafur Eggertsson, Jan Esper, Leonid Agafonov, Anatoly N. Nikolaev, Anastasia A. Knorre, Vladimir S. Myglan, Olga Churakova (Sidorova), Fritz H. Schweingruber, Daniel Nievergelt, Anne Verstege and Ulf Büntgen

Source: Arctic, Antarctic, and Alpine Research, 47(3):449-460.

Published By: Institute of Arctic and Alpine Research (INSTAAR), University of Colorado

DOI: http://dx.doi.org/10.1657/AAAR0014-063

URL: http://www.bioone.org/doi/full/10.1657/AAAR0014-063

BioOne (www.bioone.org) is a nonprofit, online aggregation of core research in the biological, ecological, and environmental sciences. BioOne provides a sustainable online platform for over 170 journals and books published by nonprofit societies, associations, museums, institutions, and presses.

Your use of this PDF, the BioOne Web site, and all posted and associated content indicates your acceptance of BioOne's Terms of Use, available at www.bioone.org/page/terms_of_use.

Usage of BioOne content is strictly limited to personal, educational, and non-commercial use. Commercial inquiries or rights and permissions requests should be directed to the individual publisher as copy right holder. 


\section{Timber logging in central Siberia is the main source for recent Arctic driftwood}

\author{
Lena Hellmann $n^{1,2,14}$ \\ Willy Tegel \\ Alexander V. Kirdyanov ${ }^{4}$ \\ Ólafur Eggertsson ${ }^{5}$ \\ Jan Esper ${ }^{6}$ \\ Leonid Agafonov ${ }^{7}$ \\ Anatoly N. Nikolaev ${ }^{8,9}$ \\ Anastasia A. Knorre ${ }^{10}$ \\ Vladimir S. Myglan ${ }^{11}$ \\ Olga Churakova (Sidorova) $)^{12}$ \\ Fritz H. Schweingruber ${ }^{l}$ \\ Daniel Nievergelt ${ }^{1}$ \\ Anne Verstege $e^{1}$ and \\ Ulf Büntgen ${ }^{1,2,13,14}$
}

${ }^{1}$ Swiss Federal Research Institute, WSL, Zurcherstrasse 111, 8903 Birmensdorf, Switzerland

${ }^{2}$ Oeschger Centre for Climate Change

Research, Falkenplatz 16, 3012 Bern,

Switzerland

${ }^{3}$ Institute for Forest Sciences IWW,

University of Freiburg, Tennebacher Str.

4, 79106 Freiburg, Germany

${ }^{4}$ V.N. Sukachev Institute of Forest

SB RAS, Akademgorodok, 660036

Krasnoyarsk, Russia

${ }^{5}$ Iceland Forest Service, Mógilsá, 116

Reykjavik, Iceland

${ }^{6}$ Johannes Gutenberg University, Johann-

Joachim-Becher-Weg 21, 55128 Mainz,

Germany

${ }^{7}$ Institute of Plant and Animal Ecology

UD RAS, 8 Marta street 202, 620144

Yekaterinburg, Russia

${ }^{8}$ North-Eastern Federal University, 58

Belinsky street, 677000 Yakutsk, Russia

${ }^{9}$ Melnikov Permafrost Institute, 36

Merzlotnaya street, 677010 Yakutsk,

Russia

${ }^{10}$ Stolby National Wildlife Nature Reserve,

26-A Kar'yernaja, 660006 Krasnoyarsk,

Russia

${ }^{11}$ Siberian Federal University, 79 Svobodny pr., 660041 Krasnoyarsk, Russia

${ }^{12} \mathrm{ETH}$ Zurich, Institute of Terrestrial

Ecosystems, Universitaetsstrasse 22, 8092

Zurich, Switzerland

${ }^{13}$ Global Change Research Centre AS CR,

Bělidla 986/4a, 60300 Brno, Czech Republic

${ }^{14}$ Corresponding authors:

Hellmann (lena.hellmann@wsl.ch) and

Büntgen (buentgen@wsl.ch)

\begin{abstract}
Recent findings indicated spruce from North America and larch from eastern Siberia to be the dominating tree species of Arctic driftwood throughout the Holocene. However, changes in source region forest and river characteristics, as well as ocean current dynamics and sea ice extent likely influence its spatiotemporal composition. Here, we present 2556 driftwood samples from Greenland, Iceland, Svalbard, and the Faroe Islands. A total of 498 out of 969 Pinus sylvestris ring width series were cross-dated at the catchment level against a network of Eurasian boreal reference chronologies. The central Siberian Yenisei and Angara Rivers account for $91 \%$ of all dated pines, with their outermost rings dating between 1804 and 1999. Intensified logging and timber rafting along the Yenisei and Angara in the mid-20th century, together with high discharge rates, explain the vast quantity of material from this region and its temporal peak ca. 1960. Based on the combined application of wood-anatomical and dendrochronological techniques on a well-replicated data set, our results question the assumption that Arctic driftwood mainly consists of millennial-old larch and spruce. Nevertheless, data from other species and regions, together with longer boreal reference chronologies, are needed for generating reliable proxy archives at the interface of marine and terrestrial environments.
\end{abstract}




\section{Introduction}

The Russian and North American river systems transport large quantities of timber from the boreal forest into the Arctic Ocean. This so-called driftwood (hereinafter DW) is either composed of felled trees that were lost during river transport (e.g., Kindle, 1921; Eggertsson, 1994a) or consists of naturally fallen trunks from river slope erosion, which enter the tributaries especially after flood and ice storm events (Alix, 2005). Moreover, discharge rates as well as riverbed and delta characteristics affect the amount of DW delivered to the ocean. After leaving the boreal rivers, the wood either sinks to the seafloor (McClain and Barry, 2014) or is rafted within the sea ice along the main ocean currents. Melted out at the ice edges in summer, it is deposited along shallow Arctic coastlines. Wood anatomical and dendrochronological techniques have proved helpful in species identification, precise dating, and provenance determination of Arctic DW (Bartholin and Hjort, 1987; Eggertsson, 1993; Hellmann et al., 2013b). However, the joint application of these techniques on a well-replicated data set of different species from widespread sampling locations, in combination with the evaluation of comprehensive networks from boreal tree-ring chronologies, is still missing (Hellmann et al., 2013a). Quantification of the amount of lost timbers is thus often challenging, and the relative contributions of the different streams and their catchment regions on the final DW composition remain unknown.

Earlier DW studies analyzed rather low numbers of samples, ranging from 13 in Fischer and Schneider (1883) to 481 in Johansen $(1998,1999)$. In consequence, these studies generated only limited insight on the contribution of specific source regions, as well as on historical ocean current and river discharge dynamics. DW from Iceland, Svalbard, Jan Mayen, and other islands mainly originated from the lower Angara region in central Siberia and northwest Russia (Eggertsson, 1993, 1994b; Johansen, 1998, 1999, 2001). Only a few DW samples from Greenland were so far successfully cross-dated against tree-ring widths reference chronologies from the Mackenzie and Yukon Rivers, but no material from North America was found further east, for example, on Svalbard or Jan Mayen (Giddings, 1952; Eggertsson and Laeyendecker, 1995). Until now, the vast majority of studies mainly found pine, larch, and spruce at sites outside of the present-day permanent Arctic sea ice extent (Ingvarson, 1910; Eurola, 1971; Häggblom, 1982; Eggertsson, 1994b; Eggertsson and Laeyendecker, 1995; Tremblay et al., 1997; Johansen, 1998, 1999, 2001). In contrast to overall younger dendrochronological dating achievements, most Holocene DW has been dated by ${ }^{14} \mathrm{C}$ measurements (Stewart and England, 1983; Dyke et al., 1997; England et al., 2008; Funder et al., 2011). In fact, most Holocene DW evidence from northern Greenland and the Canadian Arctic Archipelago suggests that spruce arrived from North America and that larch originated from eastern Siberia (Funder et al., 2011). Spatiotemporal patterns of the proportion of the different tree species have been related to ocean current dynamics and variations in source region forest characteristics, superimposed on changes in Arctic sea ice extent. However, the north Greenlandic sites introduced by Funder et al. (2011), in contrast to all previous studies, are located within the current-day sea ice area, making their findings less representative for most Arctic DW locations outside the range of sea ice extent.

Here, we present the so far largest collection of DW samples integrating different species from four Arctic Islands outside the current-day permanent sea ice extent. Wood anatomical characteristics were analyzed to identify the species composition of the entire data set, and ring widths were measured for each Pinus sylvestris sample, the most frequent species among all sites. Cross-dating potential of these pine DW series was assessed against a network of pine reference chronologies from the Eurasian boreal forest zone. Spatial field correlations of the DW chronologies against gridded climate indices of the 20th century were utilized to confirm our cross-dating results at the catchment-specific level.

\section{Material and Methods}

A total of 2556 DW samples were collected between 1996 and 2012 in Greenland $(n=1348)$, Iceland $(n=774)$, Svalbard $(n=390)$, and on the Faroe Islands $(n=44)$, an area in the North Atlantic roughly covering $62^{\circ}-78^{\circ} \mathrm{N}$ and $21^{\circ} \mathrm{W}-38^{\circ} \mathrm{E}$ (Fig. 1). The amount of DW along the different shorelines strongly varied from island to island. Few scattered trunks were found in eastern Greenland and Svalbard, whereas high trunk densities were characteristic for most shorelines in northwest Iceland. At each of the five Arctic sites, disc samples were collected from natural and logged material including small branches and large trunks. All material was archived, sanded in several steps from 80 to 400 grains $\mathrm{cm}^{-1}$, and macroscopically categorized. Morphological features were used to differentiate between deciduous and coniferous wood, as well as between pine, spruce, larch, and fir (Fig. 1). Microscopic techniques were applied not only to determine the genus, but also to support species identification. Radial sections were cut for all samples. Unstained microscopic sections enabled the separation between Pinus sylvestris and Pinus sibirica, as well as Larix sp., Picea sp., Abies sp., Salix sp., Populus sp., and Betula sp. Large pinoid pits characterize the rays of Pinus sylvestris and Pinus sibirica. Differentiation between the two pine species was possible by the occurrence of different ray-tracheid wall structures, being serrated for Pinus sylvestris but smooth for Pinus sibirica (see Hellmann et al., 2013b, for details).

Ring width patterns of all 969 Pinus sylvestris samples were measured using the program TSAPwin and a Lintab measuring device (Rinntech, Heidelberg, Germany). At least two radii per disc were produced and averaged to sample-specific mean curves. The individual mean measurement series were compared against each other to detect groups of DW samples that share statistically significant growth patterns. Further cross-dating was realized with the program PAST4 by SCIEM (Scientific Engineering and Manufacture, Vienna), which allows the synchronization of ring-width series by setting a reference and sample curves. Statistical criteria (two t-values [Baillie and Pilcher, 1973; Hollstein, 1980], Gleichläufigkeit, and correlation coefficient) are used to evaluate the best match. The visual comparison of the series excludes mismatching due to "false correlations," caused by single common peaks or low points. All series that showed $t$-values $\geq 6$, correlation coefficients $\geq 0.5$, and that passed visual control, were combined to develop floating mean chronologies. Finally, we compared the floating DW chronologies against absolutely dated pine reference chronologies from the Eurasian boreal forest zone. Age trend removal and chronology development followed standard techniques: Cubic smoothing splines with $50 \%$ frequency-response cutoff at 200 years (SPL; Cook and Peters, 1981) were applied after power-transformation (PT; Cook and Peters, 1997) and using the most recent version of the ARSTAN (ARSTAN_41d for Windows) software (Cook and Krusic, 2007). The corresponding index values were calculated as residuals between the transformed ring width measurements and their corresponding curve fits. The final chronologies were calculated using bi-weight robust means and considering the standard ARSTAN routine (STD).Temporal variance changes were further stabilized with respect to fluctuations in sample size and interseries correlation (Osborn et al., 1997). 

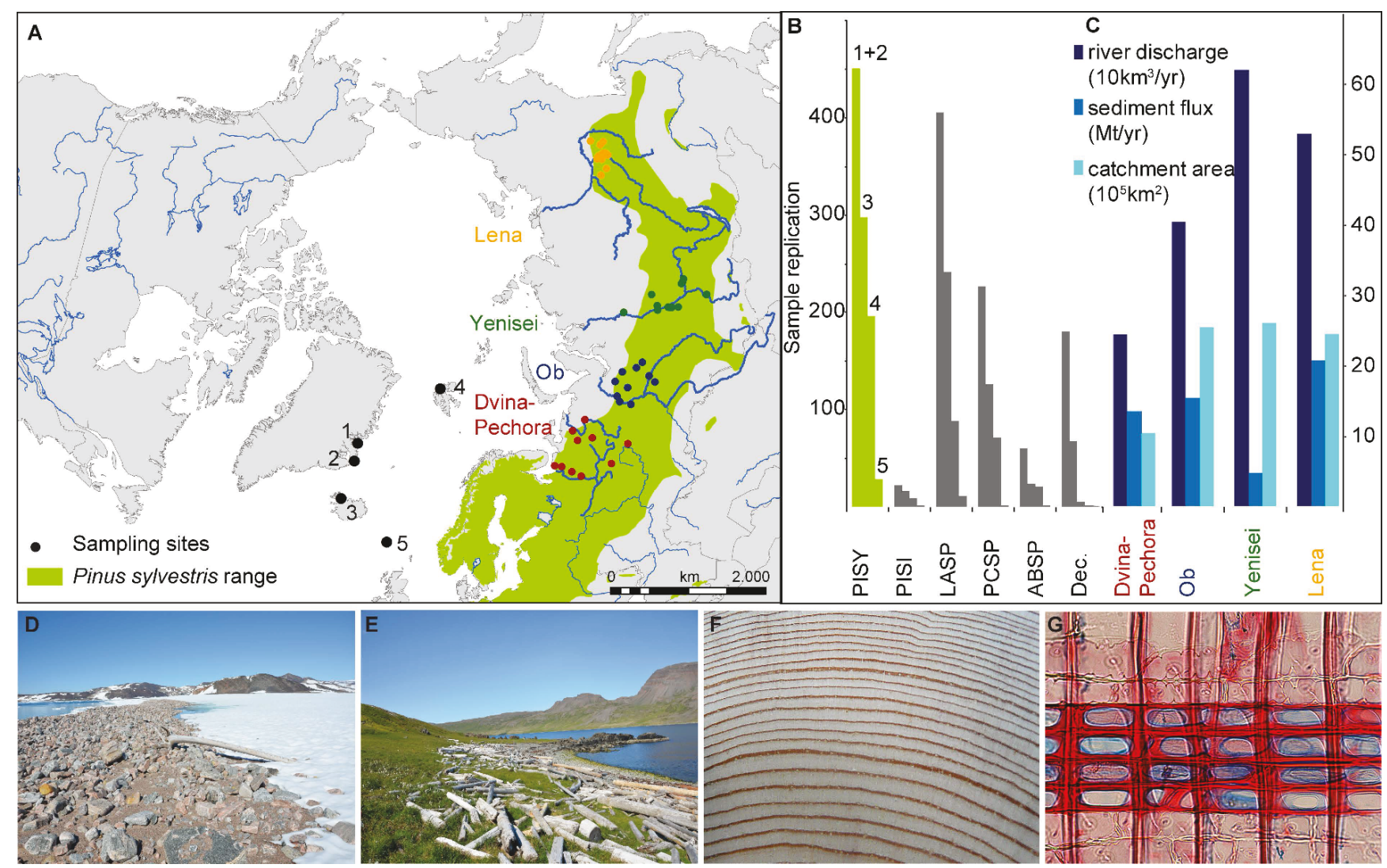

FIGURE 1. (A) Driftwood (DW) sampling sites (1: Traill [Greenland, 253 samples]; 2: Scoresbysund [Greenland, 1095]; 3: Westfjords [Iceland, 774]; 4: Ny Friesland [Svalbard, 390]; 5: Faroe Islands [44]) and Pinus sylvestris distribution area, including the major boreal river systems and reference chronologies: Dvina-Pechora (red: 11 sites and 284 series), Ob (blue: 11 sites and 615 series), Yenisei (green: 14 sites and 319 series), Lena (orange: 17 sites and 345 series). (B) DW species composition and replication (1-5 refer to the sampling sites): PISY (Pinus sylvestris; 969), PISI (Pinus sibirica; 48), LASP (Larix sp.; 747), PCSP (Picea sp.; 426), ABSP (Abies sp.; 106), and Dec. (deciduous wood; Betula sp., Salix sp., and Populus sp.; 254). (C) Characteristics of the large Eurasian river systems draining into the Arctic Ocean (Holmes et al., 2002; McClelland et al., 2004). (D) Coasts with DW on Greenland, Scoresbysund and (E) Iceland, Westfjords. (F) Macroscopic (cross section) and (G) microscopic (radial section) wood structures of Pinus sylvestris.

The resulting chronologies were truncated either at a minimum replication of five series or when the Expressed Population Signal (EPS) dropped below the commonly applied quality threshold of 0.85 (Briffa and Jones, 1990). The EPS reflects the quality of a finite chronology compared to a perfect theoretical infinite population (Wigley et al., 1984) and was herein calculated over 30-year windows with 15 years overlap.

A total of 53 absolutely dated Pinus sylvestris ring-width reference chronologies were compiled for the Russian boreal forest zone. All records originate from the $40^{\circ}-140^{\circ} \mathrm{E}$ and $60^{\circ}-90^{\circ} \mathrm{N}$ area and were either obtained from the International Tree Ring Data Bank (ITRDB, http://www.ncdc.noaa.gov/data-access/paleoclimatology-data/datasets/tree-ring) or kindly provided by Russian colleagues after personal request. First, we combined the series of the sites, for which older or updated data exist, reducing the number of site chronologies to 46. Second, Pearson correlation coefficients $(\geq 0.5)$ between the standardized chronologies were used to select the data according to their spatially coherent growth patterns in several steps. We then employed the resulting regional master chronologies to cross-date three floating Arctic DW chronologies.

Moreover, we calculated spatial field correlations between the combined DW and reference ring width chronologies and high-resolution $\left(0.5^{\circ} \times 0.5^{\circ}\right)$ gridded July-August temperature means and March-May precipitation totals (CRU TS3.21). Different chronology versions solely based on DW or living reference material, as well as using slightly different detrending techniques, were thoroughly examined against various gridded climate indices. All correlation maps, calculated over the 19611990 common period were generated via the KNMI Climate Explorer (http://climexp.knmi.nl/).

\section{Results}

DW composed of Pinus sylvestris, Pinus sibirica, Larix sp., Picea sp., Abies sp., Salix sp., Populus sp., and Betula sp. was found on all four islands (Fig. 1). Pinus sylvestris is the dominant species at all sites $(37.9 \%)$, followed by Larix sp. (29.2\%) and Picea sp. (16.7\%), Abies sp. (4.1\%), Pinus sibirica (1.9\%), and deciduous wood $(9.9 \%)$. Pine was further differentiated at the species level (Hellmann et al., 2013b, Fig. 1) allowing the spatial separation of Pinus sylvestris and Pinus sibirica across Eurasia. No pine-species originated from the North American continent.

Geographic groups of the boreal reference chronologies were consistent with the catchment areas of the large Russian river sys- 


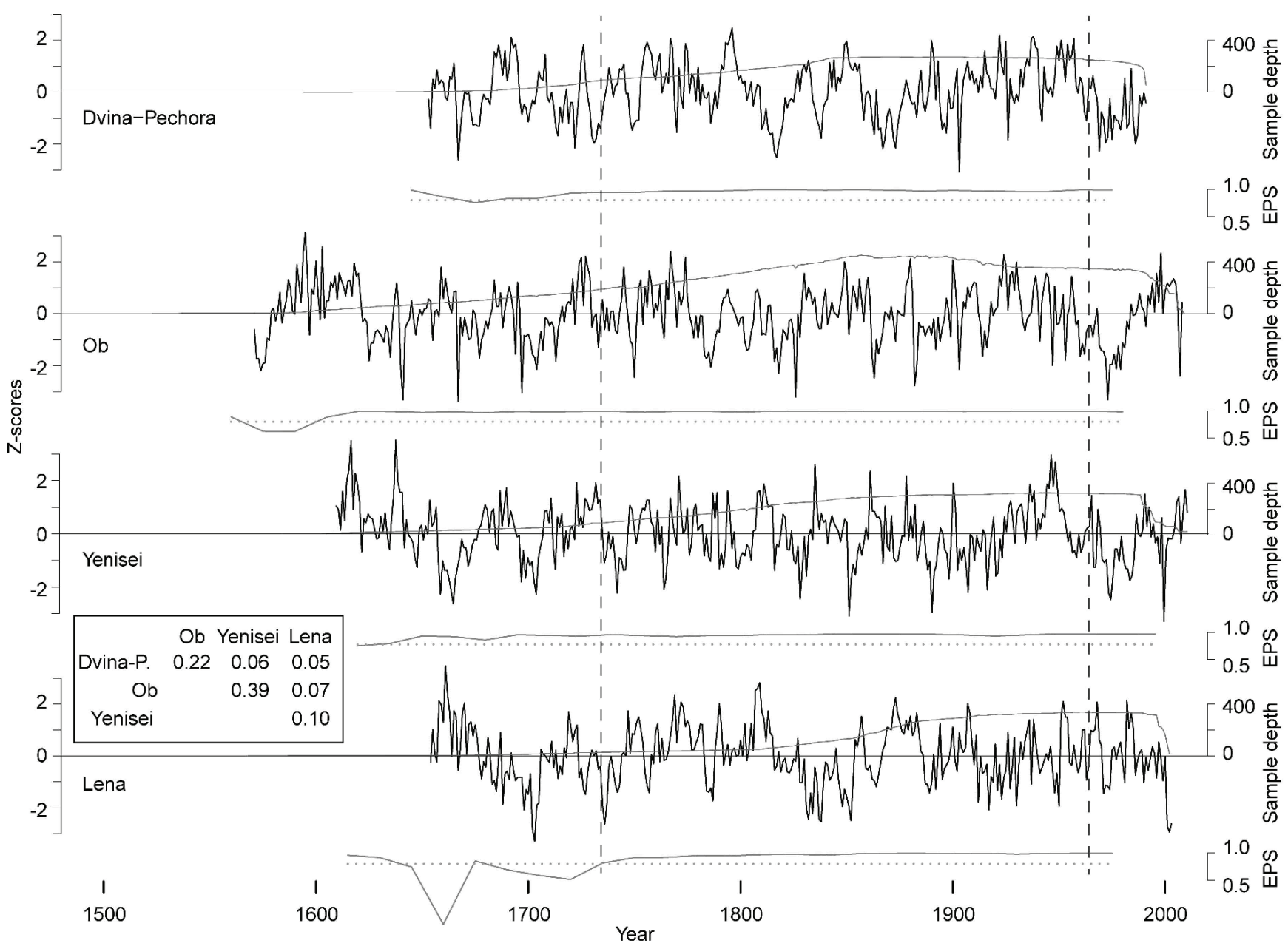

FIGURE 2. Reference chronologies of major Siberian catchment areas integrating several local site chronologies. Chronological tree-ring series were power transformed, detrended using a 200-year spline, variance stabilized, and normalized. Curves are shown for a minimum sample depth of 5 series. The dotted line indicates the EPS-value of 0.85 . The inset is showing correlation coefficients between the different reference chronologies (A.D. 1735-1964, dashed gray lines).

tems: Northern Dvina together with Pechora, Ob, Yenisei, and Lena (Fig. 1). Sites within the Dvina-Pechora region range from $60^{\circ}-67^{\circ} \mathrm{N}$ and $41^{\circ}-57^{\circ} \mathrm{E}$. Chronologies within the $\mathrm{Ob}$ catchment are located between $60^{\circ}-66^{\circ} \mathrm{N}$ and $65^{\circ}-77^{\circ} \mathrm{E}$. The Yenisei sites are within $55^{\circ}-$ $66^{\circ} \mathrm{N}$ and $88^{\circ}-96^{\circ} \mathrm{E}$. Data from the Lena represent the $60^{\circ}-64^{\circ} \mathrm{N}$ and $125^{\circ}-133^{\circ} \mathrm{E}$ area. The longest tree-ring width reference chronology spans the period 1571-2008 and represents the Ob catchment, whereas the shortest chronology covers 1654-2003 and is located in the Lena region (Fig. 2). Pearson correlation coefficients between the regional reference chronologies range from 0.22 for the nearby Dvina-Pechora and $\mathrm{Ob}$ catchments, to 0.05 for the most western and most eastern regions: Dvina-Pechora and Lena. The reference chronologies for the Dvina-Pechora and the Ob regions include 11 sites each (284 and 615 individual tree series, respectively); the Yenisei region, 14 (319 series); and the Lena, 17 (345 series) (Table 1). The whole Siberian tree-ring network includes 1563 series.

Focusing on the Pinus sylvestris DW material, we developed three floating chronologies integrating 498 of the total of 969 pine DW samples (Fig. 3). One of these floating chronologies comprises 453 series, whereas the other two contain only 28 and 17 samples, respectively. Mean segment length of all Pinus sylvestris measurement series is 121.7 years, with a minimum of 20 and a maximum of 336 years. Comparison with the living reference data from Siberia enabled $51.39 \%$ of the pine samples to be dated. Most interestingly, $90.96 \%$ (453 samples) of the dated samples originate from the central Siberian Yenisei, 5.62\% (28 samples) from the western Dvina-Pechora and $3.41 \%$ (17 samples) from the eastern Lena region (Fig. 4). No single DW sample was cross-dated against the $\mathrm{Ob}$ reference chronology. Mean interseries correlation coefficients, that is, Rbar values, for the dated DW samples range from 0.31 for the Dvina-Pechora and Yenisei region to 0.80 for the Lena region (see Table 1 for further chronology characteristics).

The applied sampling scheme including small branches and big trunks resulted in a wide age distribution range: 109 pine samples $(11.25 \%)$ contain less than 60 rings and are therefore hardly datable. A mean segment length of 144 years of all dated material, compared to only 98 years of the undated samples supports the finding that the dating of young trees often remains challenging (Table 1). Moreover, the average growth rate of the undated material is higher $(1.136 \mathrm{~mm})$, compared to the dated samples $(0.860 \mathrm{~mm})$, which results from wider rings and thus younger trees. Mean tree ages of 128, 130, and 138 years for Dvina-Pechora, Lena, and Yenisei collections are rather similar among the different catchments. 
TABLE 1

Characteristics of the boreal reference chronologies, as well as the DW measurements herein separated by sampling site and source area (No: number; MSL: mean segment length (years); AGR: average growth rate (mm); AC: lag-1 autocorrelation; Rbar: mean interseries correlation). MSL and AGR were calculated for the entire length of the chronologies, whereas AC and Rbar were calculated for the periods replicated by more than five series.

\begin{tabular}{|c|c|c|c|c|c|c|c|c|}
\hline & Site & Total length & No of series & MSL & AGR & $\begin{array}{l}\text { Length } \\
(\geq 5 \text { series })\end{array}$ & $\mathrm{AC}$ & Rbar \\
\hline \multirow{4}{*}{ References } & Dvina-Pechora & 1594-1991 & 284 & 206 & 0.802 & $1653-1991$ & 0.840 & 0.22 \\
\hline & $\mathrm{Ob}$ & 1523-2009 & 615 & 173 & 0.708 & $1571-2008$ & 0.836 & 0.283 \\
\hline & Yenisei & $1584-2010$ & 319 & 209 & 0.646 & 1609-2010 & 0.823 & 0.25 \\
\hline & Lena & 1568-2003 & 345 & 149 & 0.826 & 1654-2003 & 0.781 & 0.281 \\
\hline \multirow{5}{*}{ Greenland } & Dvina-Pechora & $1715-1980$ & 9 & 120 & 0.962 & 1840-1934 & 0.745 & 0.472 \\
\hline & Yenisei & 1654-1999 & 204 & 146 & 0.813 & 1692-1991 & 0.624 & 0.307 \\
\hline & Lena & 1689-1978 & 10 & 178 & 0.710 & $1770-1958$ & 0.829 & 0.355 \\
\hline & all dated & 1654-1999 & 223 & 146 & 0.814 & 1689-1991 & 0.843 & 0.301 \\
\hline & all undated & - & 229 & 97 & 1.088 & - & - & - \\
\hline \multirow{5}{*}{ Iceland } & Dvina-Pechora & 1669-1964 & 3 & 200 & 0.542 & - & - & - \\
\hline & Yenisei & 1631-1999 & 154 & 138 & 0.882 & 1698-1992 & 0.63 & 0.63 \\
\hline & Lena & 1755-1977 & 5 & 130 & 0.958 & $1858-1896$ & 0.548 & 0.5488 \\
\hline & all dated & 1631-1999 & 162 & 139 & 0.878 & 1688-1992 & 0.835 & 0.273 \\
\hline & all undated & - & 138 & 94 & 1.17 & - & - & - \\
\hline \multirow{4}{*}{ Svalbard } & Dvina-Pechora & $1751-1980$ & 16 & 118 & 0.928 & 1806-1963 & 0.828 & 0.257 \\
\hline & Yenisei & 1614-1994 & 78 & 150 & 0.888 & $1728-1976$ & 0.853 & 0.344 \\
\hline & all dated & 1614-1994 & 94 & 145 & 0.895 & 1728-1976 & 0.851 & 0.293 \\
\hline & all undated & - & 95 & 102 & 1.2 & - & - & - \\
\hline \multirow{4}{*}{$\begin{array}{l}\text { Faroe } \\
\text { Islands }\end{array}$} & Yenisei & $1723-1953$ & 17 & 147 & 1.123 & 1759-1948 & 0.788 & 0.384 \\
\hline & Lena & $1643-1960$ & 2 & 268 & 0.498 & - & - & 0.662 \\
\hline & all dated & $1643-1960$ & 19 & 159 & 1.057 & 1736-1949 & 0.888 & 0.307 \\
\hline & all undated & - & 9 & 160 & 1.162 & - & - & - \\
\hline \multirow{3}{*}{ Origin areas } & Dvina-Pechora & 1669-1980 & 28 & 128 & 0.928 & $1723-1964$ & 0.830 & 0.309057 \\
\hline & Yenisei & 1614-1999 & 453 & 138 & 0.882 & 1673-1998 & 0.312 & 0.312 \\
\hline & Lena & $1643-1978$ & 17 & 130 & 0.958 & 1732-1964 & 0.806 & 0.806 \\
\hline \multirow{2}{*}{ All sites } & dated & - & 498 & 144 & 0.86 & - & & - \\
\hline & undated & - & 471 & 98 & 1.136 & - & & - \\
\hline
\end{tabular}

A total of 324 dated samples most likely originate from logged trees $(65.06 \%), 67$ had a natural mortality (13.45\%), and 107 were not classified $(21.49 \%)$ (Fig. 4). The mean ages (average growth rates) do not differ much between these classes, with 124 years $(0.873 \mathrm{~mm})$ for the logged material, 134 years $(0.808$ $\mathrm{mm})$ for natural, and 155 years $(0.850 \mathrm{~mm})$ for nonclassified samples. For all three source areas, more than half of the samples were logged with $67.86 \%$ of the Dvina-Pechora material, $65.34 \%$ of the Yenisei samples, and $53.00 \%$ of the Lena wood.

The outermost rings of all dated pine samples fall in the 1614 to 1999 period (Fig. 4). The oldest pine grew from 1614-1810, originated from the Yenisei region, and was deposited on Svalbard. The youngest end year is 1999, originating from the Yenisei and found for samples on Greenland (Scoresbysund) and Iceland, where wood was collected in 2012. The minimum transport time from the falling of the tree until reaching a coast is thus constrained to 13 years. Caution is advised because bark and even sapwood were rarely preserved.

The spatial correlation patterns obtained from calibrating the combined DW plus reference chronologies against gridded climate data reinforce our cross-dating results (Fig. 3). Spatial field correlations are concordant with the respective river catchment area. The final chronologies of combined DW and living-tree series reveal significant positive spatial field correlations $(\geq 0.4)$ with either variation in temperature means (Dvina-Pechora and Yenisei data) or precipitation totals (Lena data) for the time period from 1961 to 1990 . The Dvina-Pechora and Yenisei data correlate with JulyAugust summer temperature. The Lena River chronology shows positive correlations with March-May precipitation totals. Calculations using either only DW or only reference series do not show significant correlation patterns. 


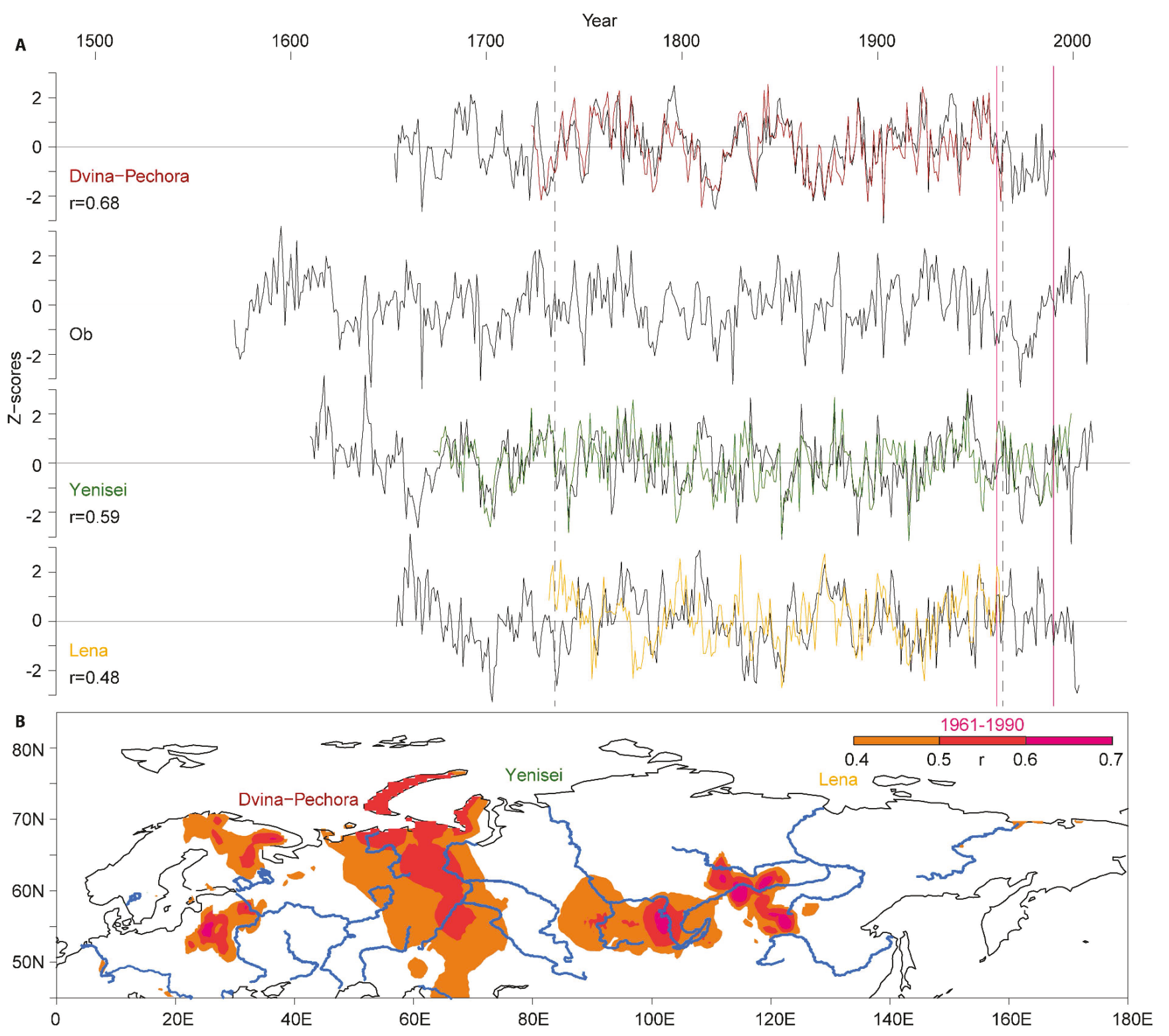

FIGURE 3. (A) Siberian reference chronologies (black) and cross-dated DW chronologies (color) truncated at a minimum of 5 series. Correlation coefficients between the reference and DW chronologies were calculated over their common period A.D. 1735-1964 (dashed gray lines). (B) Spatial correlation fields $(r \geq 0.4)$ over the period A.D. 1961-1990 (pink lines) between the combined DW-reference chronologies and July-August temperatures (for the Dvina-Pechora and Yenisei region) or March-April-May precipitation (for the Lena region), respectively.

\section{Discussion}

\section{BOREAL RIVER DISCHARGE}

Boreal river discharge is expected to increase in the 21 st century due to global warming (McClelland et al., 2004; Shiklomanov and Lammers, 2009). Implications are manifold and include changes in ocean current circulation (Peterson et al., 2002). Within the Eurasian Arctic, the central Siberian Yenisei River, draining into the Kara Sea, has the highest discharge of $620 \mathrm{~km}^{3} \mathrm{yr}^{-1}$. Riverspecific discharge rates coincide with the number of transported DW logs (Fig. 1). The Yenisei has not only the highest runoff of all large Eurasian rivers, but also represents the source of $91 \%$ of all cross-dated pine DW samples. Since pine is the most frequent species among our DW compilation, we define the Yenisei catchment as the main origin area of the recent DW found on the beaches of Greenland, Iceland, and Svalbard. Cross-dating results from earlier studies in Norway, Svalbard, Iceland, and Jan Mayen also found DW mainly to originate from this region (Eggertsson, 1993, 1994b; Johansen, 1998, 1999).

In contrast, the $\mathrm{Ob}\left(404 \mathrm{~km}^{3} \mathrm{yr}^{-1}\right)$, Dvina/Pechora $\left(241 \mathrm{~km}^{3}\right.$ $\mathrm{yr}^{-1}$ ), and Lena $\left(523 \mathrm{~km}^{3} \mathrm{yr}^{-1}\right)$ river systems all have lower discharge rates than the Yenisei (Rachold et al., 2004). Most likely not only the lower discharge rates, but also the direction of Arctic Ocean currents is a reason for fewer DW samples delivered by these river systems (Fig. 5). Despite having the highest discharge, the Yenisei contains a relatively low sediment flux (4.7

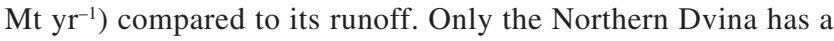

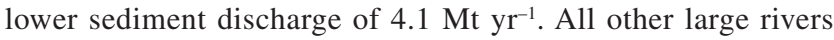




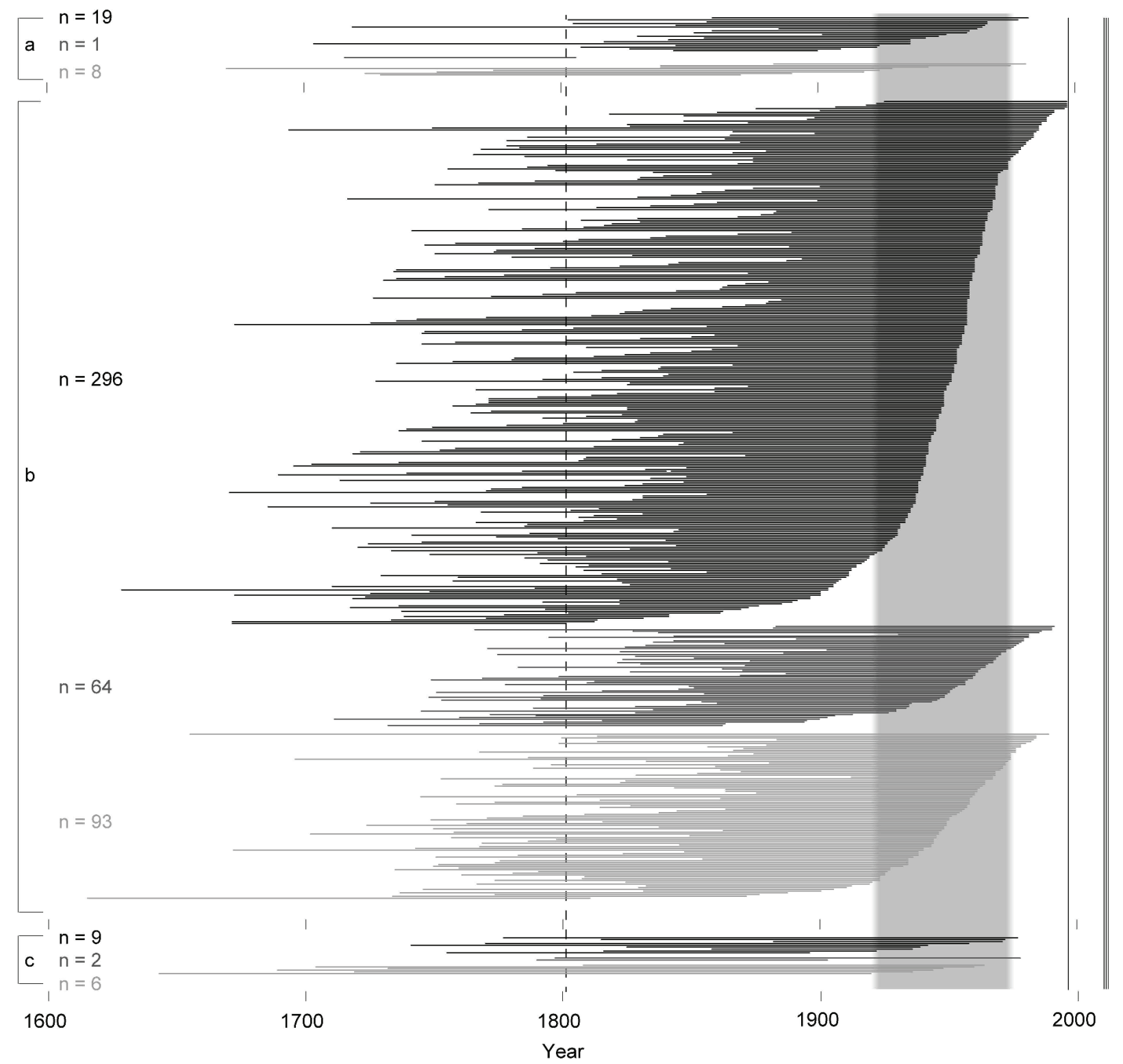

FIGURE 4. Dated DW samples per source region (a: Dvina-Pechora, b: Yenisei, c: Lena), separated into logged (black), natural (gray), and nonclassified (light gray) material. Series are sorted by end-year with A.D. 1804 as the oldest (dashed line). $n$ is the number of series included in each group. The gray shading refers to the period of high logging activities in central Siberia ca. 1920-1975. The vertical black lines refer to the DW sampling years: Ny Friesland, 1996; Traill, 2010; Scoresbysund, 2011 and 2012; and Iceland, 2012. On the Faroe Islands wood was collected over several years.

transport more sediment to the Arctic Ocean (ranging from 9.4

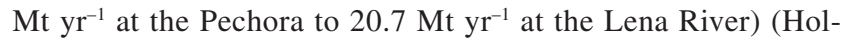
mes et al., 2002). Sediment flux rates result from riverbed and watershed properties and influence the capability of rivers to transport other material, that is, naturally eroded trees as well as logged timbers. Moreover, a high sediment flux leads to the formation of a delta system (as, for example, at the Lena and Kolyma Rivers). Even though it is not clear if a delta indeed prevents transported sediment from reaching the Arctic Ocean (Holmes et al., 2002), observations of subfossil trunks in the Lena delta $\left(72^{\circ} \mathrm{N}, 126^{\circ} \mathrm{E}\right)$ support the assumption that a huge number of logs get trapped in the delta system (Büntgen et al., 2014).
An improved understanding of long-term Arctic Ocean dynamics is important as changes in current strength and orientation can affect the expansion of the northern polar sea ice sheet (Zhang et al., 1999; Perovich and Richter-Menge, 2009). The spatial extent of the sea ice sheet is again sensitive to atmospheric climate changes through the varying ice/ocean albedo, greenhouse-gas exchange, and freshwater pathways (Morison et al., 2012; Parmentier et al., 2013; Screen et al., 2013; Pistone et al., 2014). The Arctic Ocean is frozen during winter with its maximum sea ice extent in March, but partly ice-free episodes occur during summer with the shrinking minimum sea ice extent in September (Stroeve et al., 2007). Similarly, the discharge rates of boreal rivers vary substantially throughout the year, 


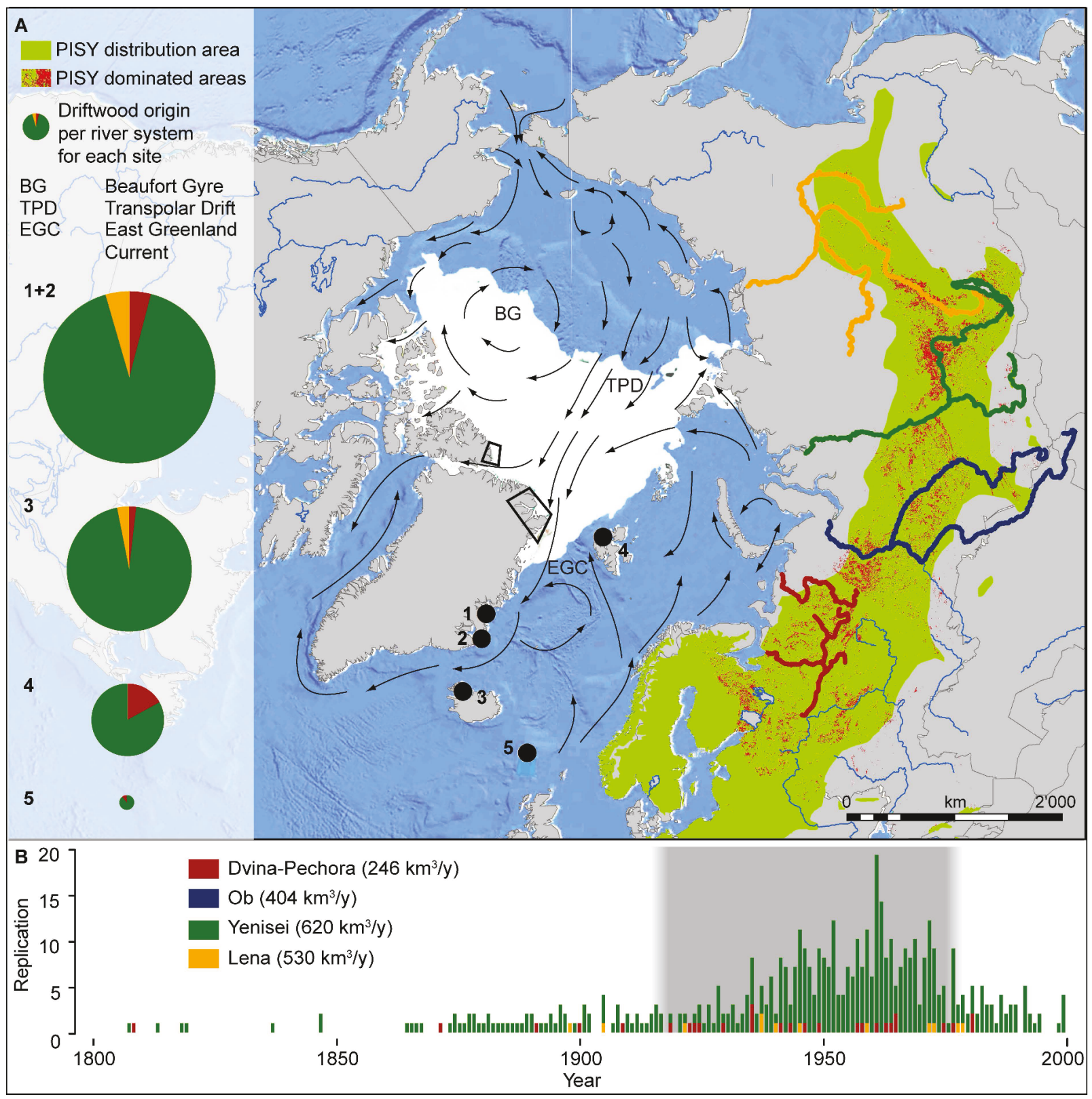

FIGURE 5. (A) Pinus sylvestris distribution area (green) with pine-dominated forests (red) shown only for Russia (Bartalev et al., 2004). Large river catchments corresponding to DW source regions are specified by different colors of the rivers. Numbers of dated samples per river are indicated for each sampling site (black dots) by the pie charts, with the size corresponding to the total number of collected samples (1+2, Greenland; 3, Iceland; 4, Svalbard; 5, Faroe Islands). Black boxes locate the sampling sites of Funder et al. (2011). Arrows illustrate the main Arctic Ocean currents (ACIA, 2005), and the white area refers to the 2010 summer sea ice extent (MDA Information System, USGS, NASA). (B) Quantity of DW samples per year (last ring) and source area. The gray shading refers to the period of high logging activities in central Siberia, which are associated with poor rafting and log driving techniques and high loss of timber (ca. 1920-1975).

with minimum values between November and April but with about $60 \%$ of the total discharge occurring from April to July (Gordeev, 2000; Lammers et al., 2001). High fluctuations of the water level, particularly during spring flood and storm events, may cause severe erosion of riverbanks and thus encourage naturally fallen trunks to enter the streams. Permafrost thawing can be an additional trigger for natural DW deposits. These DW trunks typically contain a root collar and/or branch bases, and can easily be distinguished from logged timbers free of rootstocks and snags (see Hellmann et al., 2013b, for details). Variation in seasonal runoff depends on the hydrological retention characteristics of the river. Headwater lakes as at the Mackenzie River, for instance, reduce seasonal variability, showing a fivefold variation from summer to winter compared to a tenfold variation for rivers without major headwater lakes such as the Yenisei and Lena (Carmack, 2000). 


\section{LOGGING ACTIVITIES}

The origin of wood from the varying source regions not only coincides with river discharge rates, but even more with logging and timber rafting activities of the corresponding catchments. Pinus sylvestris is the most widespread pine species in Eurasia, found from Scotland to the east coast of Siberia and typically growing on drier sites (Engelmark, 1999). Pine dominated forests are mainly found in western and central Russia and are to the east more and more superseded by larch-dominated forests (Bartalev et al., 2004).

Pinus sylvestris is the most important species for the Siberian forest industry, accounting for $\sim 34 \%$ of the total harvest (Obersteiner, 1995). In the western part of Russia, surrounding the Pechora and Northern Dvina Rivers, spruce and fir dominate, though pine was primarily the main species for lumbering. Commercial logging started around A.D. 1840. Intensive logging and log floating was conducted between 1880 and 1913, as well as later on from 1930 to 1940. After World War II, high logging activities occurred from the late 1950s to the early 1970s, but timber rafting was gradually reduced and almost entirely vanished in 1995 (Faas, 1922; Yaroshenko et al., 2001; Bartalev et al., 2004).

The region around the $\mathrm{Ob}$ River is dominated by birch-aspen and mixed forests in the south and pine forests northward (Bartalev et al., 2004). Moderate logging activities with some rafting occurred in this area only until the 1970 s, which is possibly the main reason for missing pine DW samples from the Ob. Geomorphological and hydrological conditions additionally favor the transport of DW on the Yenisei compared to the Ob. A huge floodplain of 20-60 km at the Ob River serves as a sink for most of the drifting trunks and hinders them from reaching the open ocean. The small floodplain of 300-500 $\mathrm{m}$ at the Yenisei does, however, not stop floating trunks, and the vast majority of DW can reach the Arctic currents. A higher discharge rate additionally facilitates the transport of DW on the Yenisei.

The Yenisei is the river with most intense timber rafting activities in Siberia, and source region of about $50 \%$ of the total Siberian harvest. Logging activities are concentrated in the Angara region, which is the main tributary to the Yenisei and surrounded by pine-dominated forests (Fig. 3, Bartalev et al., 2004). Most of the logged trunks were transported on the Yenisei for industrial purposes to Igarka, the main Arctic port at the Yenisei. Around 50\% of the logged wood from this area is pine (Obersteiner, 1995). Log driving and timber rafting started in the 19th century for personal use and small companies. Commercial logging increased considerably in the 1920 s and 1930 s, though up to $50 \%$ of the rafted wood got lost in these early decades. Development and application of new techniques led to a decrease of lost logs down to $\sim 1 \%$ by 1975. From 1987 on, timber rafting was reduced but not completely stopped. Today, trunks are mainly transported on the rivers using towboats and barges (Mironov, 2009). However, logs still get lost while being floated, when log-rafts are destroyed by storms, flood events, or rapids.

A total of $65 \%$ of the DW material from the Yenisei region is logged and was lost during transport in the river (Fig. 4). Despite the possibility of missing rings due to erosion processes at the outer part, cross-dating indicated that $75 \%$ of the logged timber was cut between 1920 and 1975. These felling years coincide with the period of high logging and rafting activities in Central Siberia (Figs. 4 and 5). The majority of the DW trunks originating in the Yenisei area were cut around 1961 and 1962 at all sampling sites (Fig. 5).

In the Lena region almost no pine was cut, since larch is the dominant species in this region. Timber in this region is generally of lower quality and was mainly used for the local industry without rafting (Pozdnyakov, 1969).

\section{CLIMATE CORRELATIONS}

The DW originates from the northern boreal forest zone, where trees typically show a climatic signal. Temperature responses of tree rings are common for most northern regions in Russia (Briffa et al., 1995, 2001; D'Arrigo et al., 2001; Rigling et al., 2001; Naurzbaev et al., 2002; Esper et al., 2010; Sidorova et al., 2010, 2012), but precipitation signals are rare in Siberian tree-ring chronologies (Rigling et al., 2001; Kirdyanov et al., 2013). The continental Lena sites seemingly fit in the latter scheme. Whereas winters are extremely cold in the Lena catchment, mean summer June to August temperatures for the period from 1892 to 2013 reached $17.5^{\circ} \mathrm{C}$. Low precipitation rates (mean March to August precipitation $10.7 \mathrm{~mm}$ for 1891-2013) (Lawrimore et al., 2011) primarily control tree growth in the region.

Spatial field correlations for the Dvina-Pechora region are shifted to the east/west compared to the reference chronologies, and the values are in general slightly lower than for the other two catchments $(<0.6)$. For the Lena region the spatial field correlations coincide well with the location of the reference sites and indicate the northeastern distribution limit of Pinus sylvestris (Fig. 3 ). The highest correlation values for the Yenisei River are found around the Angara River, which is its biggest tributary and characterized by the most intensive logging activities in the region. This further indicates that our logged pine DW samples originate mainly in the lower Angara region and are transported to the Arctic Ocean via the Yenisei. The combination of DW and living reference chronologies increases the correlation values compared to only DW or only living tree material and hence supports our cross-dating results.

\section{DW TRANSPORT AND SEA ICE EXTENT}

The location of DW sampling sites regarding the Arctic sea ice extent is likely one of the main influences on species composition and age of our collection.

Once in the ocean, DW either sinks or is ice-rafted with the Transpolar Drift from Siberia over the Arctic Ocean to the East Greenland current and finally to the coasts where our samples were collected (Fig. 5). The DW does not only originate from the northern distribution limit in the boreal forest, but also from around $60^{\circ} \mathrm{N}$. The trunks float for up to $8000 \mathrm{~km}$ or more within a minimum of 4-6 years (Eggertsson, 1993; Johansen, 1999). Timbers have a limited buoyancy period of several months. Birch for instance has a maximum buoyancy period of 6 months, while spruce logs can float for up to 17 months. Pine and larch have maximum buoyancy periods of 10 months (Häggblom, 1982). Considering the several-year-long journey over the ocean, DW logs must be transported in or on the ice to avoid sinking. Hence sea ice is the essential transport medium for DW, independently of the species. At the same time, DW is only deposited on shallow and ice-free coastlines. Modern DW is sparse at the sites described by Funder et al. (2011) at the beaches of Northern Greenland, where sea ice also persists throughout the short summer season. The overall amount of DW is also much lower compared to our sites in Eastern Greenland and Iceland (Funder et al., 2011, Fig. 1).

The high percentage of pine among the logged timbers is most likely one reason for the young age of the wood. The proportion of natural and hence possibly older wood is higher for larch and spruce. 
A widespread distribution of sampling sites together with a high replication of samples and wood-anatomical analyses favor the development of a data set representing the regional species and age composition.

\section{EARLY SETTLEMENT AND DW AGE}

Wood has been an essential requirement for early settlements all over the world. In the treeless areas of the high northern latitudes, DW was the crucial resource for fire, to build houses, kayak frames, weapons, and more generally all kind of tools (Alix, 2005). First signs of human cultures in Greenland are found from 2500 B.C. on. Distribution varied over the centuries with a total abandonment of Greenland and the High Arctic from A.D. 1 to 700. The northern part of Greenland was inhabited for 1200 years before and after the abandonment by Independence (2500-1900 B.C.), Early Dorset (800-400 B.C.), and Thule (A.D. 1200-1400) cultures. No human signs are found for 2800 years in Northern Greenland. The southern part, on the contrary, was inhabited for 3300 years. The Saqqaq (1900-800 B.C.) and the Greenlandic Dorset (400 B.C.-A.D. 1) cultures are only found in the southern part, which was hence uninhabited for just 700 years (Grønnow and Sørensen, 2006). Spatiotemporal changes in the abundance of DW might be essential for the rise and fall of ancient northern cultures. The use of wood as fire resource eliminates it as a natural archive. We assume that in North-East Greenland, where sea ice persists throughout the summer season, DW was used less by humans and old wood can still be found. However, old wood might also be lost due to past natural hazards, as, for example, storm surges, and wood degradation, especially on the more southern sites on Iceland and the Faroer Islands. DW from high and old beach ridges in areas with little human influence hence most likely contains a much higher proportion of old material than our samples, which were collected mainly at the shoreline in areas surrounded by human settlements.

\section{FOREST TYPES AND SPECIES DISTRIBUTION}

Since Pinus sylvestris does not exist on the North American continent, only tree-ring width chronologies from Eurasia were considered as references. Since the pan-Arctic watershed barely includes Scandinavia (McClelland et al., 2004), we also excluded any data west of $40^{\circ} \mathrm{E}$. More southern chronologies were ignored because of different growth patterns and missing common signals when compared to the northern reference records and thus also the DW compilations. The possibility of identifying DW samples at the species level by means of wood anatomy, thereby excluding North America as a source region, facilitated the cross-dating of pine samples. Provenance determination of other species is more complex since reference chronologies from both Siberia and North America need to be considered. The higher proportion of natural DW might also result in a wider age distribution, likely requiring longer (i.e., composite) reference chronologies comprising living and relict material. The fact that we could not build any other floating chronology within the DW series shows that at least for pine, there was most likely no earlier period when comparably high amounts of DW were deposited along the endless coastlines of the Arctic islands.

The overall fraction of DW originating from North America is expected to be small, as the vast majority of pine samples ( $P i$ nus sylvestris) has been demonstrated to originate from Eurasia. Moreover, the second most abundant DW species, larch, is also much more dominant in Siberia than in North America.

\section{Acknowledgments}

This study is part of the ongoing "DW project" supported by the Eva Mayr-Stihl Foundation and the Swiss Federal Research Institute WSL. Additional support was received from the Czech project "Building up a multidisciplinary scientific team focused on drought" (No. CZ.1.07/2.3.00/20.0248). V. Trotsiuk and L. Hülsmann provided technical support. J. Ejdesgaard and E. av Kák collected DW samples on the Faroe Islands, and D. Galván and F. Charpentier contributed to discussion. Tree-ring data for Siberia were partly assembled under the Russian Science Foundation project 14-14-00295. We are thankful to all ITRDB contributors. We thank three anonymous reviewers and A. Jennings for helpful and constructive comments.

\section{References Cited}

ACIA, 2005: Arctic Climate Impact Assessment. Cambridge: Cambridge University Press, 1042 pp.

Alix, C., 2005: Deciphering the impact of change on the driftwood cycle: contribution to the study of human use of wood in the Arctic. Global and Planetary Change, 47(2): 83-98.

Baillie, M. G., and Pilcher, J. R., 1973: A simple crossdating program for tree-ring research. Tree-Ring Bulletin, 33: 7-14.

Bartalev, S., Ershov, D., Isaev, A., Potapov, P., Turubanova, S., and Yaroshenko, A., 2004: Russia's Forests. TerraNorte Information System. RAS Space Research Institute.

Bartholin, T., and Hjort, C., 1987: Dendrochronological studies of recent driftwood on Svalbard. In L. Kairukstis, L. B., and E. Feliksik (ed.), Methods of Dendrochronology. Warsaw: Polish Academy of Sciences, Systems Resarch Institute, 207-219.

Briffa, K., and Jones, P., 1990: Basic chronology statistics and assessment. In Cook, E. R., and Kairiukstis, L. A. (eds.), Methods of Dendrochronology: Applications in the Environmental Sciences. Dordrecht, Netherlands: Kluwer Academic Publishers, 137-152.

Briffa, K. R., Jones, P. D., Schweingruber, F. H., Shiyatov, S. G., and Cook, E. R., 1995: Unusual twentieth-century summer warmth in a 1,000-year temperature record from Siberia. Nature, 376(6536): $156-159$.

Briffa, K. R., Osborn, T. J., Schweingruber, F. H., Harris, I. C., Jones, P. D., Shiyatov, S. G., and Vaganov, E. A., 2001: Low-frequency temperature variations from a northern tree ring density network. Journal of Geophysical Research: Atmospheres (1984-2012), 106(D3): 2929-2941.

Büntgen, U., Kirdyanov, A. V., Hellmann, L., Nikolaev, A. N., and Tegel, W., 2014: Cruising an archive: on the palaeoclimatic value of the Lena Delta. The Holocene, 24(5): 627-630.

Carmack, E. C., 2000: The Arctic Ocean's freshwater budget: sources, storage and export. In Lewis, E. L. (ed.), The Freshwater Budget of the Arctic Ocean. Dordrecht, Netherlands: Kluwer Academic Publishers, 91-126.

Cook, E. R., and Peters, K., 1981: The smoothing spline: a new approach to standardizing forest interior tree-ring width series for dendroclimatic studies. Tree-Ring Bulletin, 41: 45-53.

Cook, E. R., and Peters, K., 1997: Calculating unbiased tree-ring indices for the study of climatic and environmental change. The Holocene, 7(3): 361-370.

Cook, E. R., and Krusic, P. J., 2007: ARSTAN-a tree-ring standardization program based on detrending and autoregressive time series modeling, with interactive graphics. Tree-Ring Laboratory, Lamont Doherty Earth Observatory of Columbia University, Palisades, New York.

D’Arrigo, R., Jacoby, G., Frank, D., Pederson, N., Cook, E., Buckley, B., Nachin, B., Mijiddorj, R., and Dugarjav, C., 2001: 1738 years of Mongolian temperature variability inferred from a tree-ring width chronology of Siberian pine. Geophysical Research Letters, 28(3): 543-546. 
Dyke, A. S., England, J., Reimnitz, E., and Jetté, H., 1997: Changes in driftwood delivery to the Canadian Arctic Archipelago: the hypothesis of postglacial oscillations of the Transpolar Drift. Arctic, 50(1): 1-16.

Eggertsson, Ó., 1993: Origin of the driftwood on the coasts areas of Iceland, a dendrochronological study. Jökull, 43: 15-32.

Eggertsson, Ó., 1994a: Mackenzie River driftwood: a dendrochronological study. Arctic, 47(2): 128-136.

Eggertsson, Ó., 1994b: Driftwood as an indicator of relative changes in the influx of Arctic and Atlantic water into the coastal areas of Svalbard. Polar Research, 13(2): 209-218.

Eggertsson, Ó., and Laeyendecker, D., 1995: A dendrochronological study of the origin of driftwood in Frobisher Bay, Baffin Island, NWT, Canada. Arctic and Alpine Research, 27(2): 180-186.

Engelmark, O., 1999: Boreal forest disturbances. In Walker, L. R. (ed.), Ecosystems of Disturbed Ground. Amsterdam, Netherlands: Elsevier Science B.V., 161-186.

England, J. H., Lakeman, T. R., Lemmen, D. S., Bednarski, J. M., Stewart, T. G., and Evans, D. J., 2008: A millennial-scale record of Arctic Ocean sea ice variability and the demise of the Ellesmere Island ice shelves. Geophysical Research Letters, 35(19).

Esper, J., Frank, D., Büntgen, U., Verstege, A., Hantemirov, R. M., and Kirdyanov, A. V., 2010: Trends and uncertainties in Siberian indicators of 20th century warming. Global Change Biology, 16(1): 386-398.

Eurola, S., 1971: The driftwoods of the Arctic Ocean. Report of the Kevo Subarctic Research Station, 774-780.

Faas, V. V., 1922: Lesa seyernogo raiona i ih ekspluatatsiya. Petrograd: Yo Yo Media (in Russian).

Fischer, D., and Schneider, J., 1883: Untersuchungen einiger Treibhölzer von der Insel Jan Mayen. Die österreichische Polarstation Jan Mayen, Beobachtungsergebnisse. Kaiserliche Akademie der Wissenschaften, 3(7B): 17-24 (in German).

Funder, S., Goosse, H., Jepsen, H., Kaas, E., Kjær, K. H., Korsgaard, N. J., Larsen, N. K., Linderson, H., Lyså, A., and Möller, P., 2011: A 10,000-year record of Arctic Ocean sea-ice variability_view from the beach. Science, 333(6043): 747-750.

Giddings, J. L., 1952: Driftwood and problems of Arctic sea currents. Proceedings of the American Philosophical Society, 96(2): 129-142.

Gordeev, V. V., 2000: River input of water, sediment, major ions, nutrients and trace metals from Russian territory to the Arctic Ocean. In Lewis, E. L. (ed.), The Freshwater Budget of the Arctic Ocean. Dordrecht, Netherlands: Springer, 297-322.

Grønnow, B., and Sørensen, M., 2006: Palaeo-eskimo migrations into Greenland: the Canadian connection. In Dynamics of Northern Societies. Copenhagen: Nationalmuseet, National Museum Studies in Archaeology and History, Volume 10, 59-74.

Häggblom, A., 1982: Driftwood in Svalbard as an indicator of sea ice conditions. Geografiska Annaler. Series A. Physical Geography, 64(A): 81-94.

Hellmann, L., Tegel, W., Eggertsson, Ó., Schweingruber, F., Blanchette, R., Kirdyanov, A. V., Gärtner, H., and Büntgen, U., 2013a, On the importance of anatomical classification in Arctic driftwood research. In Helle, G., Gärtner, H., Beck, W., Heinrich, I., Heussner, K. U., Müller, A., and Sanders, T. (eds.), TRACE—Tree Rings in Archaeology, Climatology, and Ecology. Conference proceedings, GFZ Potsdam, 160-165.

Hellmann, L., Tegel, W., Eggertsson, Ó., Schweingruber, F. H., Blanchette, R., Kirdyanov, A., Gärtner, H., and Büntgen, U., 2013b: Tracing the origin of Arctic driftwood. Journal of Geophysical Research: Biogeosciences, 118(1): 68-76.

Hollstein, E., 1980: Mitteleuropäische Eichenchronologie: Trierer dendrochronologische Forschungen zur Archäologie und Kunstgeschichte. Mainz am Rhein: Philipp von Zabern (in German).

Holmes, R. M., McClelland, J. W., Peterson, B. J., Shiklomanov, I. A., Shiklomanov, A. I., Zhulidov, A. V., Gordeev, V. V., and Bobrovitskaya, N. N., 2002: A circumpolar perspective on fluvial sediment flux to the Arctic Ocean. Global Biogeochemical Cycles, 16(4): 45-41-45-14.
Ingvarson, F., 1910: Die Treibhölzer auf dem Ellesmere-Land. Kristiania (Oslo), Norway: The Society of Arts and Sciences of Kristiania.

Johansen, S., 1998: The origin and age of driftwood on Jan Mayen. Polar Research, 17(2): 125-146.

Johansen, S., 1999: Origin of driftwood in north Norway and its relevance for transport routes of drift ice and pollution to the Barents Sea. Science of the Total Environment, 231(2): 201-225.

Johansen, S., 2001: A dendrochronological analysis of driftwood in the Northern Dvina delta and on northern Novaya Zemlya. Journal of Geophysical Research: Oceans (1978-2012), 106(C9): 1992919938.

Kindle, E., 1921: Mackenzie River driftwood. Geographical Review, 11(1): 50-53.

Kirdyanov, A. V., Prokushkin, A. S., and Tabakova, M. A., 2013: Treering growth of Gmelin larch under contrasting local conditions in the north of Central Siberia. Dendrochronologia, 31(2): 114-119.

Lammers, R. B., Shiklomanov, A. I., Vörösmarty, C. J., Fekete, B. M., and Peterson, B. J., 2001: Assessment of contemporary Arctic river runoff based on observational discharge records. Journal of Geophysical Research: Atmospheres (1984-2012), 106(D4): 33213334.

Lawrimore, J. H., Menne, M. J., Gleason, B. E., Williams, C. N., Wuertz, D. B., Vose, R. S., and Rennie, J., 2011: An overview of the Global Historical Climatology Network monthly mean temperature data set, version 3. Journal of Geophysical Research: Atmospheres (19842012), 116: D19121, http://dx.doi.org/10.1029/2011JD016187.

McClain, C., and Barry, J., 2014: Beta-diversity on deep-sea wood falls reflects gradients in energy availability. Biology Letters, 10(4): http://dx.doi.org/10.1098/rsbl.2014.0129.

McClelland, J. W., Holmes, R. M., Peterson, B. J., and Stieglitz, M., 2004: Increasing river discharge in the Eurasian Arctic: consideration of dams, permafrost thaw, and fires as potential agents of change. Journal of Geophysical Research: Atmospheres (1984-2012), 109(D18): http://dx.doi.org/10.1029/2004JD004583.

Mironov, G. S., 2009: Lesnaya niva Krasnoyar'ya (in Russian). Krasnoyarsk: Litera-Print, 191 pp.

Morison, J., Kwok, R., Peralta-Ferriz, C., Alkire, M., Rigor, I., Andersen, R., and Steele, M., 2012: Changing Arctic Ocean freshwater pathways. Nature, 481(7379): 66-70.

Naurzbaev, M. M., Vaganov, E. A., Sidorova, O. V., and Schweingruber, F. H., 2002: Summer temperatures in eastern Taimyr inferred from a 2427-year late-Holocene tree-ring chronology and earlier floating series. The Holocene, 12(6): 727-736.

Obersteiner, M., 1995: Status and Structure of the Forest Industry in Siberia. Laxenburg: International Institute for Applied System Analyses (IIASA).

Osborn, T., Briffa, K., and Jones, P., 1997: Adjusting variance for sample size in tree-ring chronologies and other regional mean timeseries. Dendrochronologia, 15: 89-99.

Parmentier, F.-J. W., Christensen, T. R., Sørensen, L. L., Rysgaard, S., McGuire, A. D., Miller, P. A., and Walker, D. A., 2013: The impact of lower sea-ice extent on Arctic greenhouse-gas exchange. Nature Climate Change, 3(3): 195-202.

Perovich, D. K., and Richter-Menge, J. A., 2009: Loss of sea ice in the Arctic. Annual Review of Marine Science, 1: 417-441.

Peterson, B. J., Holmes, R. M., McClelland, J. W., Vörösmarty, C. J., Lammers, R. B., Shiklomanov, A. I., Shiklomanov, I. A., and Rahmstorf, S., 2002: Increasing river discharge to the Arctic Ocean. Science, 298(5601): 2171-2173.

Pistone, K., Eisenman, I., and Ramanathan, V., 2014: Observational determination of albedo decrease caused by vanishing Arctic sea ice. Proceedings of the National Academy of Sciences, 111(9): 3322-3326.

Pozdnyakov, L. K., 1969: Lesa Yakutskoi ASSR (Forests of Yakutia Republic), Lesa SSSR (Forests of the USSR). Moscow: Nauka, 469537 (in Russian).

Rachold, V., Eicken, H., Gordeev, V., Grigoriev, M., Hubberten, H.-W., Lisitzin, A., Shevchenko, V., and Schirrmeister, L., 2004: Modern 
Terrigenous Organic Carbon Input to the Arctic Ocean, The Organic Carbon Cycle in the Arctic Ocean. New York: Springer, 33-55.

Rigling, A., Waldner, P. O., Forster, T., Bräker, O. U., and Pouttu, A., 2001: Ecological interpretation of tree-ring width and intraannual density fluctuations in Pinus sylvestris on dry sites in the central Alps and Siberia. Canadian Journal of Forest Research, 31(1): 18-31.

Screen, J. A., Simmonds, I., Deser, C., and Tomas, R., 2013: The atmospheric response to three decades of observed Arctic sea ice loss. Journal of Climate, 26(4): 1230-1248.

Shiklomanov, A., and Lammers, R., 2009: Record Russian river discharge in 2007 and the limits of analysis. Environmental Research Letters, 4(4): 045015, http://dx.doi.org/10.1088/17489326/4/4/045015.

Sidorova, O. V., Siegwolf, R. T., Saurer, M., Naurzbaev, M. M., Shashkin, A. V., and Vaganov, E. A., 2010: Spatial patterns of climatic changes in the Eurasian north reflected in Siberian larch tree-ring parameters and stable isotopes. Global Change Biology, 16(3): 1003-1018.

Sidorova, O. V., Saurer, M., Myglan, V. S., Eichler, A., Schwikowski, M., Kirdyanov, A. V., Bryukhanova, M. V., Gerasimova, O. V., Kalugin, I. A., and Daryin, A. V., 2012: A multi-proxy approach for revealing recent climatic changes in the Russian Altai. Climate Dynamics, 38(1-2): 175-188.
Stewart, T. G., and England, J., 1983: Holocene sea-ice variations and paleoenvironmental change, northernmost Ellesmere Island, NWT, Canada. Arctic and Alpine Research, 15(1): 1-17.

Stroeve, J., Holland, M. M., Meier, W., Scambos, T., and Serreze, M., 2007: Arctic sea ice decline: faster than forecast. Geophysical Research Letters, 34(9): http://dx.doi.org/10.1029/2007GL029703.

Tremblay, L. B., Mysak, L., and Dyke, A., 1997: Evidence from driftwood records for century-to-millennial scale variations of the high latitude atmospheric circulation during the Holocene. Geophysical Research Letters, 24(16): 2027-2030.

Wigley, T. M., Briffa, K. R., and Jones, P. D., 1984: On the average value of correlated time series, with applications in dendroclimatology and hydrometeorology. Journal of Climate and Applied Meteorology, 23(2): 201-213.

Yaroshenko, A. Y., Potapov, P. V., and Turubanova, S. A., 2001: Malonarushennye lesnye territorii Evropeiskogo severa Rossii. Moscow: Greenpeace Russia, 75 pp. (in Russian).

Zhang, Y., Maslowski, W., and Semtner, A. J., 1999: Impact of mesoscale ocean currents on sea ice in high-resolution Arctic ice and ocean simulations. Journal of Geophysical Research: Oceans (1978-2012), 104(C8): 18409-18429.

MS accepted December 2014 